\title{
MINIMASI MAKESPAN DENGAN PENJADWALAN PRODUKSI PADA TIPE PRODUKSI BERULANG
}

\author{
IMRON KUSWANDI \\ Jurusan Teknik Industri Universitas Trunojoyo \\ E-mail: imronkuswandi@gmail.com
}

\begin{abstract}
ABSTRAK
Secara metodologis, ada beberapa masalah dalam metode penjadwalan produksi yang telah tersedia. Metode penjadwalan produksi yang telah tersedia seringkali kurang mampu untuk memberikan gambaran kondisi dari sistem nyata. Hal ini ditandai dengan asumsi bahwa setiap operasi harus selesai sebelum operasi lainnya selesai. Asumsi ini tidak tepat jika diterapkan dalam jenis produksi berulang seperti yang terjadi di PT. X Gresik. Karena ada beberapa masalah dalam metode penjadwalan produksi konvensional, dalam penelitian ini metode penjadwalan produksi konvensional dimodifikasi dengan menggunakan Microsoft excel sehingga metode ini memungkinkan untuk menangani kasus penjadwalan produksi dalam jenis produksi berulang. Selanjutnya, dengan menggunakan metode penjadwalan produksi yang dimodifikasi dengan menggunakan Microsoft excel, penjadwalan dapat dicapai dengan makespan yang lebih baik (makespan = 471,17 jam), sehingga utilitas fasilitas produksi juga lebih optimal dibandingkan dengan hasil penjadwalan produksi dengan pendekatan konvensional (makespan = 893,7 jam).
\end{abstract}

Kata kunci: penjadwalan produksi, minimasi makespan, produksi berulang

\begin{abstract}
Methodologically there are some problems in the methods of scheduling production which have been available. In the methods of scheduling production which have been available, it is often less capable for giving the real condition images from the real systems. It is indicated by the given assumption that each operation should be finished previously before the other operations are done. This case is inappropriate if applied in the repetitive production types as happened in X Gresik, Co. Ltd. Because there are some problems in the methods of scheduling conventional production, so in this research the methods of scheduling conventional production are modified by using Microsoft excel application software, this method enables to handle the case of scheduling production in the types of repetitive production. Furthermore, by using the methods of scheduling production modified by using Microsoft excel application software, the scheduling can be achieved by the better makespan (makespan $=471.17$ hours), so the production facility utilities are also more optimal compared to production scheduling results by conventional approach (makespan $=893.7$ hours).
\end{abstract}

Key words: production scheduling, makespan minimation, repetitive production

\section{PENDAHULUAN}

Sebagaimana kasus-kasus penjadwalan produksi pada umumnya, kasus penjadwalan produksi yang terjadi di PT. X Gresik sebenarnya merupakan kasus penjadwalan biasa yang bisa diselesaikan dengan menggunakan metode penjadwalan produksi yang sudah ada (pendekatan konvensional). Namun karena terdapat permasalahan secara metodologis dari metode penjadwalan produksi konvensional, maka pada penelitian ini digunakan penjadwalan produksi yang dimodifikasi dengan menggunakan software aplikasi Microsoft Excel.

Permasalahan tersebut adalah bahwa pada metode penjadwalan produksi yang sudah ada seringkali kurang mampu memberikan gambaran keadaan yang sebenarnya dari sistem nyata. Hal ini ditandai dengan terdapatnya asumsi bahwa setiap operasi harus diselesaikan terlebih dahulu sebelum operasi yang lain dikerjakan (Rahayu, 2000 dan Pinedo, 1985). Hal ini tidak sesuai jika diterapkan pada tipe produksi berulang sebagaimana yang terjadi di PT X Gresik. Gambar 1 di bawah ini memberikan ilustrasi dari kondisi tersebut.

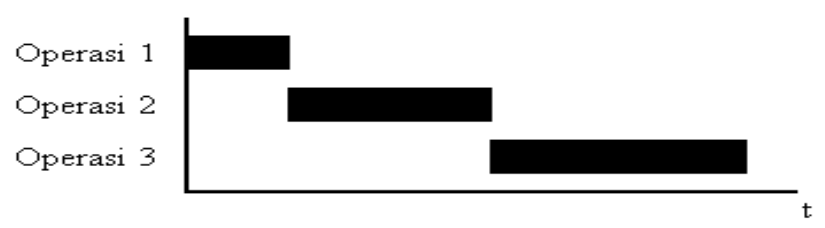

Gambar 1. Ilustrasi Penjadwalan Produksi dengan Pendekatan Konvensional 
Sedangkan karakteristik tipe produksi berulang (repetitive production) adalah jumlah unit yang diproduksi banyak serta antar unit produksi tidak mempunyai perbedaan secara signifikan sehingga dapat memakai resource produksi yang identik.

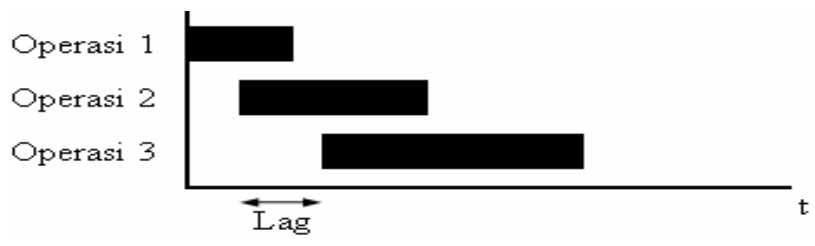

Gambar 2. Karakteristik Tipe Produksi Berulang

Gambar 2 tersebut menjelaskan bahwa waktu mulai operasi 2 dapat dilakukan setelah waktu lag dari waktu mulai operasi 1 dilakukan (waktu lag adalah waktu dimana terjadi transfer antaroperasi). Penetapan waktu transfer memperhitungkan jarak tempuh untuk memindahkan produk antaroperasi dan ukuran transfer batch. Dari ilustrasi pada Gambar 1 dan Gambar 2 terlihat bahwa pendekatan konvensional kurang tepat jika digunakan untuk menangani kasus-kasus penjadwalan produksi untuk tipe produksi berulang karena akan diperoleh hasil penjadwalan dengan makespan yang lebih lama. Tujuan dari penelitian ini adalah melakukan penjadwalan produksi pada tipe produksi berulang yang terdapat di PT X Gresik untuk mendapatkan makespan minimal. Sedangkan yang dimaksud dengan makespan adalah waktu yang diperlukan untuk menyelesaikan seluruh job pada shop.

\section{METODE}

Penjadwalan merupakan pengaturan waktu dari suatu kegiatan operasi. Penjadwalan mencakup kegiatan mengalokasikan fasilitas, peralatan ataupun tenaga kerja bagi suatu kegiatan operasi dan menentukan urutan pelaksanaan kegiatan operasi. Dalam hierarki pengambilan keputusan, penjadwalan merupakan langkah terakhir sebelum dimulainya operasi. Tujuan penjadwalan untuk meminimalkan waktu proses, waktu tunggu langganan, dan tingkat persediaan, serta penggunaan yang efisien dari fasilitas, tenaga kerja, dan peralatan. Penjadwalan dapat didefinisikan sebagai pengaturan waktu dari suatu kegiatan yang mencakup kegiatan mengalokasikan fasilitas, peralatan atau tenaga kerja bagi suatu kegiatan operasi dan menentukan urutan pelaksanaan kegiatan operasi. Penjawalan juga dapat diartikan sebagai proses pengalokasian sumber-sumber guna melaksanakan sekumpulan tugas dalam jangka waktu tertentu. Berbagai teknik dapat diterapkan untuk penjadwalan, teknik yang digunakan tergantung dari volume produksi, variasi produk, keadaan operasi, dan kompleksitas dari pekerjaan sendiri dan pengendalian yang diperlukan selama proses.

Kebanyakan perusahaan menyelesaikan pekerjaan secara bersamaan, karena itu perlu menggabungkan beberapa jadwal kerja. Penggabungan ini dimungkinkan apabila tanggal penyerahan atau selesai untuk setiap pekerjaan dapat diketahui dan seluruh penggabungan tersebut akan

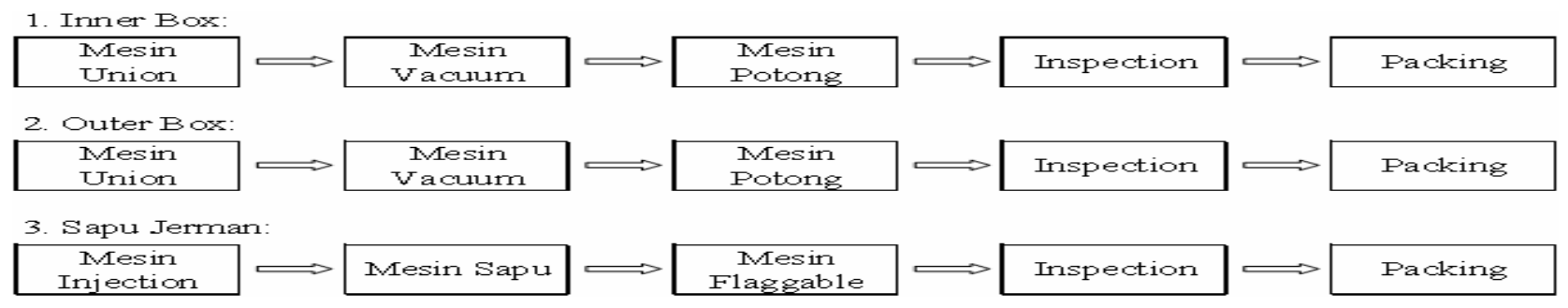

Gambar 3. Urutan Proses dari ke-3 Jenis Produk yang Diproduksi PT X Gresik

Tabel 2. Data Kuantitas Produk dan Kecepatan Produksi Tiap Work Center

\begin{tabular}{|c|c|c|c|c|c|c|c|c|c|}
\hline$J o b$ & Kuantitas Produk/Kecepatan Produksi & M1 & M2 & M3 & M4 & M5 & M6 & M7 & M8 \\
\hline \multirow[t]{2}{*}{ JobA } & Kuantitas produk (unit) & 20.000 & - & 20.000 & 20.000 & - & - & 20.000 & 20.000 \\
\hline & Kecepatan produksi (unit per jam) & 96,62 & - & 105,26 & 406,78 & - & - & 162,16 & 125,00 \\
\hline \multirow[t]{2}{*}{ JobB } & Kuantitas produk (unit) & 15.000 & - & 15.000 & 15.000 & - & - & 15.000 & 15.000 \\
\hline & Kecepatan produksi (unit per jam) & 96,15 & - & 105,53 & 413,79 & - & - & 166,67 & 127,66 \\
\hline \multirow[t]{2}{*}{ JobC } & Kuantitas produk (unit) & - & 20.000 & - & - & 20.000 & 20.000 & 20.000 & 20.000 \\
\hline & Kecepatan produksi (unit per jam) & - & 146,85 & - & - & 173,91 & 235,29 & 157,89 & 130,43 \\
\hline
\end{tabular}


dilaksanakan oleh setiap bagian proses sepanjang periode yang direncanakan. Proses penggabungan ini disebut penjadwalan (scheduling) dan hasilnya secara sederhana disebut jadwal (schedule) atau jadwal produksi (production schedule) secara keseluruhan. Salah satu kunci keberhasilan dalam meningkatkan efisiensi dalam unit operasi adalah kemampuan untuk menyusun jadwal secara efektif. Namun dalam menyusun jadwal secara efektif terdapat beberapa kesulitan, yaitu kesulitan dalam mengidentifikasi tujuan dari jadwal yang sedang dilaksanakan dan jumlah yang sangat besar dari jadwal yang mungkin.

Persoalan penjadwalan adalah persoalan pengalokasian pekerjaan ke mesin, pada kondisi mesin mempunyai kapasitas dan jumlah terbatas. Secara umum masalah penjadwalan dapat dijelaskan sebagai n job (J1, J2, ..., Jn) yang harus diproses di $\mathrm{m}$ mesin (M1, M2,..,Mn). Waktu yang diperlukan untuk memproses pekerjaan J1 pada mesin M adalah $P$ setiap job harus diproses tanpa dihentikan selama waktu proses $\mathrm{p}$ mesin hanya dapat menangani satu job pada saat yang sama, dan secara terus menerus tersedia sejak waktu nol (time zero). Pemecahan permasalahan yang diinginkan adalah mendapatkan jadwal yang optimal, yaitu menyelesaikan semua pekerjaan dengan mendapatkan jadwal yang optimal yaitu menyelesaikan semua pekerjaan dengan adanya keterbatasan kapasitas dan ketersediaan mesin dengan memenuhi fungsi tujuannya.

Pemecahan masalah penjadwalan jobshop dapat dilakukan dengan dua pendekatan: 1) Pendekatan optimasi.
Pendekatan ini dapat dilakukan dengan beberapa macam cara, diantaranya : Teknik Integer Programming, Teknik Branch and Bound. 2) Pendekatan Heuristik. Pendekatan ini dapat dilakukan dengan beberapa macam cara, di antaranya: Priority Dispatching, Sampling, Probabilistik Dispatching. Algoritma adalah sebuah prosedur atau urutan langkah sebuah Algoritma optimal akan selalu menghasilkan jadwal yang terbaik sedangkan Algoritma Heuristik biasanya menghasilkan jadwal yang sangat baik (seringkali optimal, namun tidak dapat dipastikan) dengan usaha yang relatif lebih kecil. Cara yang sering digunakan dalam pendekatan heuristik adalah penggunaan priority dispatching rule, yaitu aturan yang menentukan/memilih operasi mana yang akan dilaksanakan dan mengalokasikannya ke mesin yang menganggur. Dispatching rule diklasifikasikan menjadi tiga jenis: Simple Rules, Kombinasi dari Simple Rules, Kombinasi dari Simple Rules dengan Indeks. Ada dua Algoritma Heuristik dasar untuk jobshop yang dapat digunakan yaitu Algoritma penjadwalan aktif dan Algoritma penjadwalan non-delay. Kedua Algoritma ini pada dasarnya sama, perbedaan yang terjadi adalah pada kriteria untuk menyelesaikan konflik pada mesin yang ditemukan. Algoritma pertama menggunakan penyelesaian berbasis aktif yang lain berbasis non-delay.

Penelitian ini membahas analisis penjadwalan produksi di PT X Gresik agar dapat diperoleh makespan minimal. Fokus penelitian pada 3 jenis produk yang diproduksi, yaitu Inner Box, Outer Box dan Sapu Jerman. Masing-masing produk diproses pada mesin dapat dilihat pada gambar 3. Pada penelitian ini, di samping dilakukan penjadwalan produksi dengan pendekatan konvensional yang

Tabel 3. Hasil Perhitungan $a_{i}$ dan $b_{i}$ pada Metode Dannenbring

\begin{tabular}{ccccccccccc}
\hline JOB & M1 & M2 & M3 & M4 & M5 & M6 & M7 & M8 & $\mathbf{a}_{\text {i }}$ & $\mathbf{b}_{\text {i }}$ \\
\hline JobA & 207,0 & - & 190,0 & 49,2 & - & - & 123,3 & 160,0 & $3.448,5$ & $3.117,0$ \\
JobB & 156,0 & - & 142,1 & 36,3 & - & - & 90,0 & 117,5 & $2.579,6$ & $2.297,4$ \\
JobC & - & 136,2 & - & - & 115,0 & 85,0 & 126,7 & 153,3 & $2.075,0$ & $3.470,7$ \\
\hline
\end{tabular}

Maka, urutan penjadwalannya adalah: JobC - JobA - JobB

Tabel 4. Hasil Perhitungan Penjadwalan dengan Algoritma Dudeck Teuton Smith

\begin{tabular}{|c|c|c|c|c|c|c|c|c|c|c|c|c|c|c|}
\hline \multirow{2}{*}{ JOB } & \multicolumn{2}{|c|}{$k=1$} & \multicolumn{2}{|c|}{$k=2$} & \multicolumn{2}{|c|}{$\mathbf{k}=\mathbf{3}$} & \multicolumn{2}{|c|}{$k=4$} & \multicolumn{2}{|c|}{$\mathbf{k}=\mathbf{5}$} & \multicolumn{2}{|c|}{$k=6$} & \multicolumn{2}{|c|}{$k=7$} \\
\hline & $\mathbf{M}_{\mathrm{I}}$ & $\mathbf{M}_{\text {II }}$ & $\mathbf{M}_{1}$ & $\mathbf{M}_{\mathrm{II}}$ & $\mathbf{M}_{I}$ & $\mathbf{M}_{\mathrm{II}}$ & $\mathbf{M}_{I}$ & $\mathbf{M}_{\mathrm{II}}$ & $\mathbf{M}_{1}$ & $\mathbf{M}_{\mathrm{II}}$ & $\mathbf{M}_{\mathbf{I}}$ & $\mathbf{M}_{\mathrm{II}}$ & $\mathbf{M}_{\mathbf{I}}$ & $\mathbf{M}_{\mathrm{II}}$ \\
\hline$\overline{J J o b A}$ & 207,0 & 160,0 & 207,0 & 283,3 & 397,0 & 283,3 & 446,2 & 283,3 & 446,2 & 332,5 & 446,2 & 522,5 & 446,2 & 522,5 \\
\hline$J o b$ B & 156,0 & 117,5 & 156,0 & 207,5 & 298,1 & 207,5 & 334,4 & 207,5 & 334,4 & 243,8 & 334,4 & 385,9 & 334,4 & 385,9 \\
\hline$J o b \mathrm{C}$ & 0,0 & 153,3 & 153,3 & 280,0 & 136,2 & 365,0 & 136,2 & 480,0 & 251,2 & 480,0 & 336,2 & 480,0 & 336,2 & 616,2 \\
\hline Penjadwalan & \multicolumn{2}{|c|}{ C-A-B } & \multicolumn{2}{|c|}{ C-A-B } & \multicolumn{2}{|c|}{ C-A-B } & \multicolumn{2}{|c|}{ C-A-B } & \multicolumn{2}{|c|}{ C-A-B } & \multicolumn{2}{|c|}{ C-A-B } & \multicolumn{2}{|c|}{ C-A-B } \\
\hline
\end{tabular}




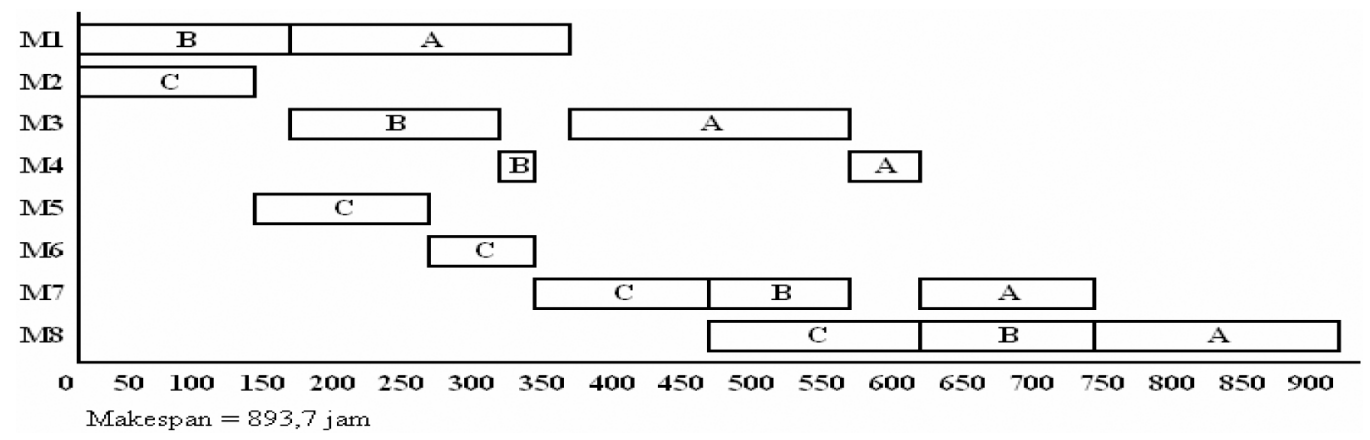

Gambar 4. Gantt Chart Penjadwalan Berdasarkan Algoritma Palmer

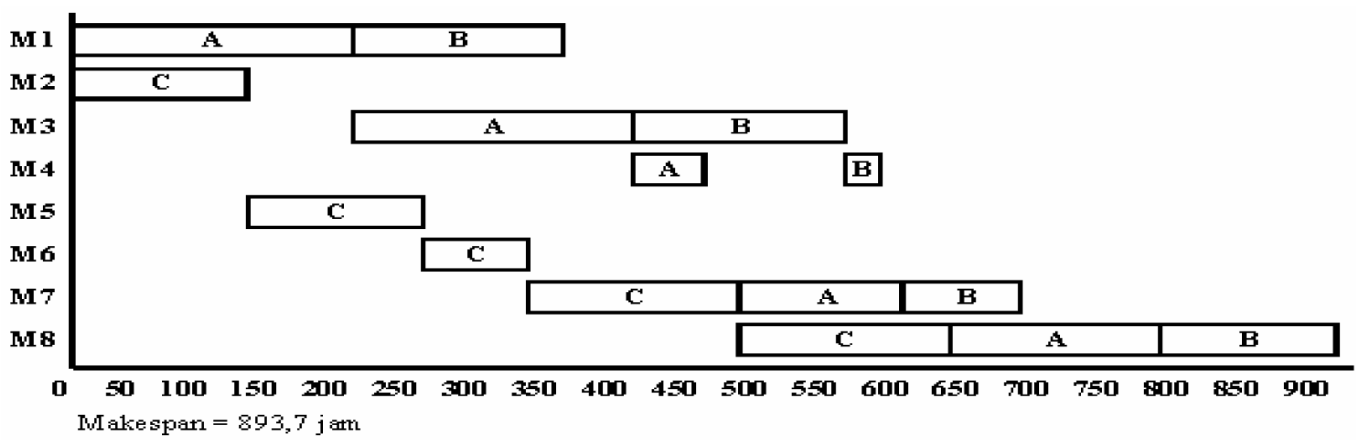

Gambar 5. Gantt Chart Penjadwalan Berdasarkan Algoritma Dannenbring/Algoritma DTS

dimodifikasi dengan menggunakan software aplikasi Microsoft Excel, juga dilakukan penjadwalan produksi dengan menggunakan metode penjadwalan produksi yang sudah ada (pendekatan konvensional) sebagai pembanding. Pengumpulan data permintaan dari ke3 jenis produk tersebut dalam bulan Februari 2010 serta data kuantitas produk dan kecepatan produksi tiap work center adalah sebagai berikut:

Tabel 1. Data Permintaan PT. X Gresik

\begin{tabular}{lcc}
\hline \multicolumn{1}{c}{ Nama Produk } & \multicolumn{1}{c}{ Ukuran } & Permintaan \\
\hline Inner Box $($ Job A $)$ & $600 \times 520 \times 4,1 \mathrm{~mm}$ & 20.000 unit \\
Outer Box $($ Job B $)$ & $600 \times 520 \times 3,5 \mathrm{~mm}$ & 15.000 unit \\
Sapu Jerman $($ Job C) & $1250 \times 350 \times 50 \mathrm{~mm}$ & 20.000 unit \\
\hline
\end{tabular}

Dari Tabel 1 dapat dilihat bahwa permintaan untuk PT. X Gresik senantiasa bervariasi untuk setiap produk.

Keterangan: M1: Mesin Union (untuk menghasilkan lembaran), M2: Mesin Injection (untuk menghasilkan block sapu), M3: Mesin Vacuum (untuk membentuk bodi), M4: Mesin Potong (untuk memotong/meratakan bodi), M5: Mesin Sapu (untuk mengisi bulu sapu), M6: Mesin Flaggable (untuk menghaluskan sebagian bulu sapu), M7: Pemeriksaan/inspeksi, dan M8: Pengepakan.

\section{HASIL DAN PEMBAHASAN}

Penjadwalan produksi dengan pendekatan konvensional dilakukan dengan algoritma Palmer dan Dannenbring. Penjadwalan job dengan algoritma Palmer dimulai dengan menghitung slope index (SI) dari masing-masing job dengan formula: $\left.\mathrm{SI}=\sum_{\mathrm{j}=1}^{\mathrm{m}}=\{\mathrm{m}-(2 \cdot \mathrm{j}-1)\} \cdot \mathrm{t}_{\mathrm{ij}}\right\} \quad$ selanjutnya $j o b$ dijadwalkan atas dasar slope index terbesar. Dari hasil perhitungan, diperoleh slope index sebagai berikut: JobA $=-331,5$ JobB $=282,2$ dan $J o b \mathrm{C}=$ $1.395,7$, sehingga urutan penjadwalannya adalah: JobC - JobB - JobA.

Penjadwalan job dengan algoritma Dannenbring dimulai dengan menghitung waktu proses seolaholah untuk mesin pertama: $a_{i}=\sum_{j=1}^{m}=(m-. j+1) \cdot t_{i j}$ dan menghitung waktu proses seolah-olah untuk mesin kedua: $b_{i}=\sum_{j=1}^{m}=j \cdot t_{i j}$. Kemudian job dijadwalkan atas dasar algoritma Johnson dengan parameter $\mathrm{a}_{\mathrm{i}}=$ waktu proses di mesin- 1 dan $\mathrm{b}_{\mathrm{i}}=$ waktu proses di mesin-mesin. Hasil perhitungan $a_{i}$ dan $b_{i}$ bisa dilihat pada tabel 3 .

Langkah-langkah penjadwalan job atas dasar algoritma Johnson adalah ${ }^{(i)}$ : mengidentifikasi $\mathrm{k}=1$; $\mathrm{L}=\mathrm{n}$, kemudian list job yang belum terjadwal $\left(\mathrm{J}_{1}, \mathrm{~J}_{2}\right.$, 
..., $\mathrm{J}_{\mathrm{n}}{ }^{(\mathrm{ii})}$. Selanjutnya cari waktu proses terkecil dari job-job tersebut. Bila waktu proses terkecil untuk $\mathrm{J}_{1}$ pada mesin pertama, maka jadwalkan $J_{1}$ pada $M_{1}$ pada posisi ke-k, kemudian hilangkan $\mathrm{J}_{1}$ dari list job yang belum terjadwal, setelah itu tentukan $\mathrm{k}=\mathrm{k}+1$. Jika semua job sudah terjadwal maka penjadwalan selesai. Jika belum, maka ulangi langkah sebelumnya, yaitu mencari waktu proses terkecil dari job-job yang belum terjadwal. Sedangkan bila waktu proses terkecil untuk $\mathrm{J}_{1}$ pada mesin kedua, maka jadwalkan $\mathrm{J}_{1}$ pada $\mathrm{M}_{2}$ pada posisi ke-L, kemudian hilangkan $\mathrm{J}_{1}$ dari list job yang belum terjadwal, setelah itu tentukan $\mathrm{L}=\mathrm{L}-1$. Jika semua job sudah terjadwal maka penjadwalan selesai. Jika belum, maka ulangi langkah sebelumnya, yaitu mencari waktu proses terkecil dari job-job yang belum terjadwal.
Penjadwalan job dengan Algoritma Dudeck Teuton Smith dimulai dengan mengidentifikasi $\mathrm{k}=1$, hitung $\mathrm{t}_{\mathrm{i} .1}{ }^{*}=\sum_{\mathrm{k}=1}^{\mathrm{k}}=\mathrm{t}_{\mathrm{i} . \mathrm{k}}$ dan $\mathrm{t}_{\mathrm{i} .2}{ }^{*}=\sum_{\mathrm{k}=1}^{\mathrm{k}}=\mathrm{t}_{\mathrm{i} . \mathrm{m}-\mathrm{k}+1}$, kemudian urutkan job atas Algoritma Johnson. Hitung makespan. Selanjutnya identifikasi $\mathrm{k}=\mathrm{k}+1$. Jika

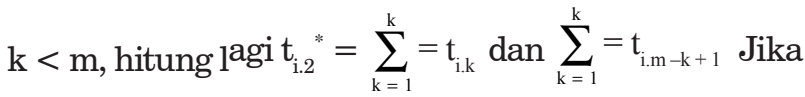
$\mathrm{k} \geq \mathrm{m}$, pilih makespan terkecil dari penjadwalan. Hasil perhitungan selengkapnya diberikan oleh Tabel 4.

Untuk mendapatkan makespan dari penjadwalan di atas serta untuk mendapatkan informasi penjadwalan secara visual, digunakan Gantt Chart untuk masing-masing metode (Gambar 4 dan Gambar 5).

Tabel 6. Judul Kolom pada Tabel Penjadwalan Produksi

\begin{tabular}{|c|c|}
\hline Kolom & Keterangan \\
\hline M & Mendefinisikan work center yang digunakan \\
\hline Produk & Nama produk (job) yang dikerjakan \\
\hline Operasi & Operasi produksi \\
\hline Produk/Operasi & Kunci unik dengan menggabungkan jenis produk yang dikerjakan dengan nomor operasi \\
\hline Quantity (Unit) & Kuantitas produk yang dikerjakan (unit) \\
\hline Unit per jam & Kecepatan produksi tiap work center untuk pengerjaan tiap produk \\
\hline Durasi (Jam) & Durasi pengerjaan job untuk tiap operasi (jam) \\
\hline Operasi Sebelumnya & Operasi sebelumnya dari urutan pengerjaan job \\
\hline Baris Operasi Sblmnya & Baris dari tabel dimana operasi sebelumnya berada \\
\hline Ukuran Batch & Jumlah output tiap kali transfer pada operasi selanjutnya \\
\hline Lag Batch Pertama & Waktu lag yang dibutuhkan untuk transfer batch pertama \\
\hline Ukuran Batch Terakhir & Ukuran batch yang ditransfer terakhir kali \\
\hline Lag Batch Terakhir & Waktu lag yang dibutuhkan untuk transfer batch terakhir \\
\hline Start Operasi Sblmnya & Waktu start dari operasi sebelumnya \\
\hline Stop Operasi Sblmnya & Waktu stop dari operasi sebelumnya \\
\hline Waktu Tunggu & Lamanya waktu tunggu \\
\hline Start & Waktu mulai pengerjaan job untuk tiap operasi \\
\hline Stop & Waktu selesai pengerjaan job untuk tiap operasi \\
\hline Efektif Unit per Jam & Menunjukkan output produk efektif yang diproduksi tiap work center \\
\hline
\end{tabular}

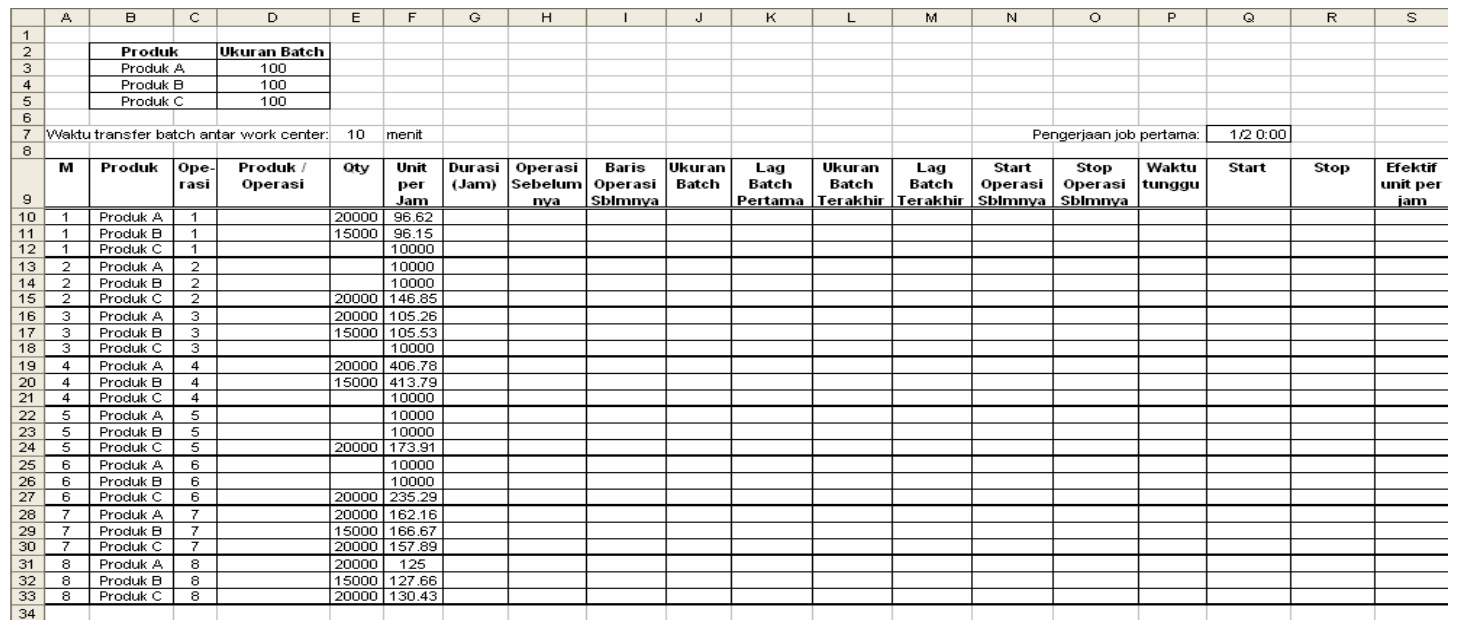

Gambar 6. Pengisian Data 
Dari Gantt Chart tersebut, diperoleh penjadwalan produksi terbaik yang dapat meminimasi makespan berdasarkan Algoritma Palmer dengan urutan penjadwalan: JobC - JobB - JobA atau berdasarkan Algoritma Dudeck Teuton Smith dan Algoritma Dannenbring dengan urutan penjadwalan: JobC JobA - JobB, masing-masing dengan makespan 893,7 jam.

Pada penelitian ini dilakukan penjadwalan produksi berdasarkan informasi bahwa pada tipe produksi berulang terdapat karakteristik dimana perpindahan produk antaroperasi menggunakan pallet/bin, karena kuantitas produk yang besar sehingga untuk memindahkannya dibutuhkan suatu tempat (pallet/bin). Output dari satu operasi dikumpulkan pada satu pallet dan dikumpulkan pada stok antara. Transfer output pada stok antara ditetapkan pada jumlah tertentu (batch). Jika output yang terkumpul pada stok antara sesuai dengan jumlah batch, dilakukan transfer menuju operasi selanjutnya sehingga waktu lag tiap produk dihitung berdasarkan ukuran transfer batch dan waktu transfer antaroperasi.

Langkah pertama yang dilakukan adalah melakukan perhitungan lag batch pertama. Lag batch pertama adalah waktu lag yang terjadi karena dilakukan transfer batch yang pertama kali. Waktu lag untuk transfer batch berikutnya adalah sama dengan waktu lag pada transfer batch yang pertama, kecuali untuk transfer batch terakhir. Perhitungan waktu lag diperlukan karena penjadwalan produksi dilakukan pada tipe produksi berulang. Langkah berikutnya adalah menghitung ukuran batch terakhir. Karena terakhir, maka jumlah output dalam satu batch belum tentu sama dengan ukuran transfer batch. Dari perhitungan ukuran batch terakhir, dapat ditentukan lag batch terakhir, yaitu waktu lag yang terjadi karena dilakukan transfer batch yang terakhir.

Selanjutnya dilakukan penjadwalan produksi dengan pendekatan konvensional yang dimodifikasi dengan menggunakan software aplikasi microsoft excel. Dari penjadwalan ini, dapat ditentukan makespan-nya. Sedangkan untuk mendapatkan informasi penjadwalan secara visual, maka dibuatkan Gantt Chart. Langkah terakhir adalah melakukan re-sequencing sesuai dengan urutan penjadwalan berdasarkan algoritma penjadwalan produksi yang lain. Selanjutnya dari sini dapat ditentukan penjadwalan terbaik yang dapat memberikan makespan minimal. Lag batch pertama adalah waktu lag yang terjadi karena dilakukan transfer batch yang pertama kali.

Perhitungan lag batch pertama membutuhkan 3 input, yaitu: ukuran transfer batch produk (yaitu jumlah output operasi pada setiap kali transfer pada operasi selanjutnya), kecepatan operasi sebelumnya (dibutuhkan untuk menentukan waktu pembuatan batch pertama) serta waktu transfer batch. Lag batch pertama ditentukan berdasarkan formula berikut: Lag batch pertama $=\frac{\mathrm{b}_{\mathrm{i}}}{\mathrm{kp}_{\mathrm{op}}-1}+\mathrm{t}_{\mathrm{b}}$, dengan $\mathrm{b}_{\mathrm{i}}=$ ukuran transfer batch, $\mathrm{kp}_{\mathrm{op}-1}=$ kecepatan produksi operasi sebelumnya, dan $\mathrm{t}_{\mathrm{b}}=$ waktu untuk transfer batch selanjutnya. Batch terakhir adalah batch yang terakhir kali ditransfer dari satu operasi. Karena terakhir, maka jumlah output dalam satu batch belum tentu sama dengan ukuran transfer batch.

Ukuran batch terakhir adalah hasil sisa dari pembagian kuantitas produk yang diproduksi dengan ukuran transfer batch produk. Setelah diketahui ukuran batch terakhir, dapat ditentukan lag batch terakhir berdasarkan formula berikut ini:

Lag batch terakhir $=\mathrm{t}_{\mathrm{b}}+\frac{\mathrm{b}_{\mathrm{i}}}{\mathrm{kp}_{\mathrm{op}}-1}$, dengan: $\mathrm{b}_{\mathrm{t}}=$ ukuran transfer batch terakhir, $\mathrm{kp}_{\mathrm{op}}=$ kecepatan produksi, dan $\mathrm{t}_{\mathrm{b}}=$ waktu untuk transfer batch selanjutnya.

Prosedur penjadwalan produksi dengan menggunakan software aplikasi microsoft excel adalah sebagai berikut.

Tabel 5. Judul Kolom pada Tabel Ukuran Batch

\begin{tabular}{ll}
\hline \multicolumn{1}{c}{ Kolom } & \multicolumn{1}{c}{ Keterangan } \\
\hline Produk & Nama produk (job) yang dikerjakan \\
Ukuran Batch & $\begin{array}{l}\text { Jumlah output tiap kali transfer pada operasi } \\
\text { selanjutnya }\end{array}$ \\
\hline
\end{tabular}

Pada Tabel 5, diisikan data ukuran batch yang akan digunakan sebagai referensi dalam penjadwalan produksi untuk menentukan ukuran batch tiap produk. Sedangkan pada tabel penjadwalan produksi, pengisian data sesuai urutan work center yang mengerjakan job. Pengisian data selengkapnya ditunjukkan pada Gambar 6.

Pada sel E7 diisi dengan waktu transfer batch antar work center, yaitu 10 menit. Pada sel E12, E13, E14, E18, E21, E22, E23, E25 dan E26 dikosongi karena tidak ada job yang diproses. Sedangkan sel F12, F13, F14, F18, F21, F22, F23, F25 dan F26 diisi dengan bilangan positif besar agar waktu yang diperlukan untuk memenuhi 1 batch sangat singkat (seharusnya nol karena tidak ada job yang diproses) sehingga waktu lag hanya meliputi waktu transfer batch antar work center. "Produk/Operasi" digunakan sebagai kunci unik dengan menggabungkan jenis produk yang dikerjakan dengan nomor operasi. Formula penggabungan: $R I G H T(\mathrm{~B} 10,1)$ akan mencari satu karakter dari kanan pada sel B10 dan 


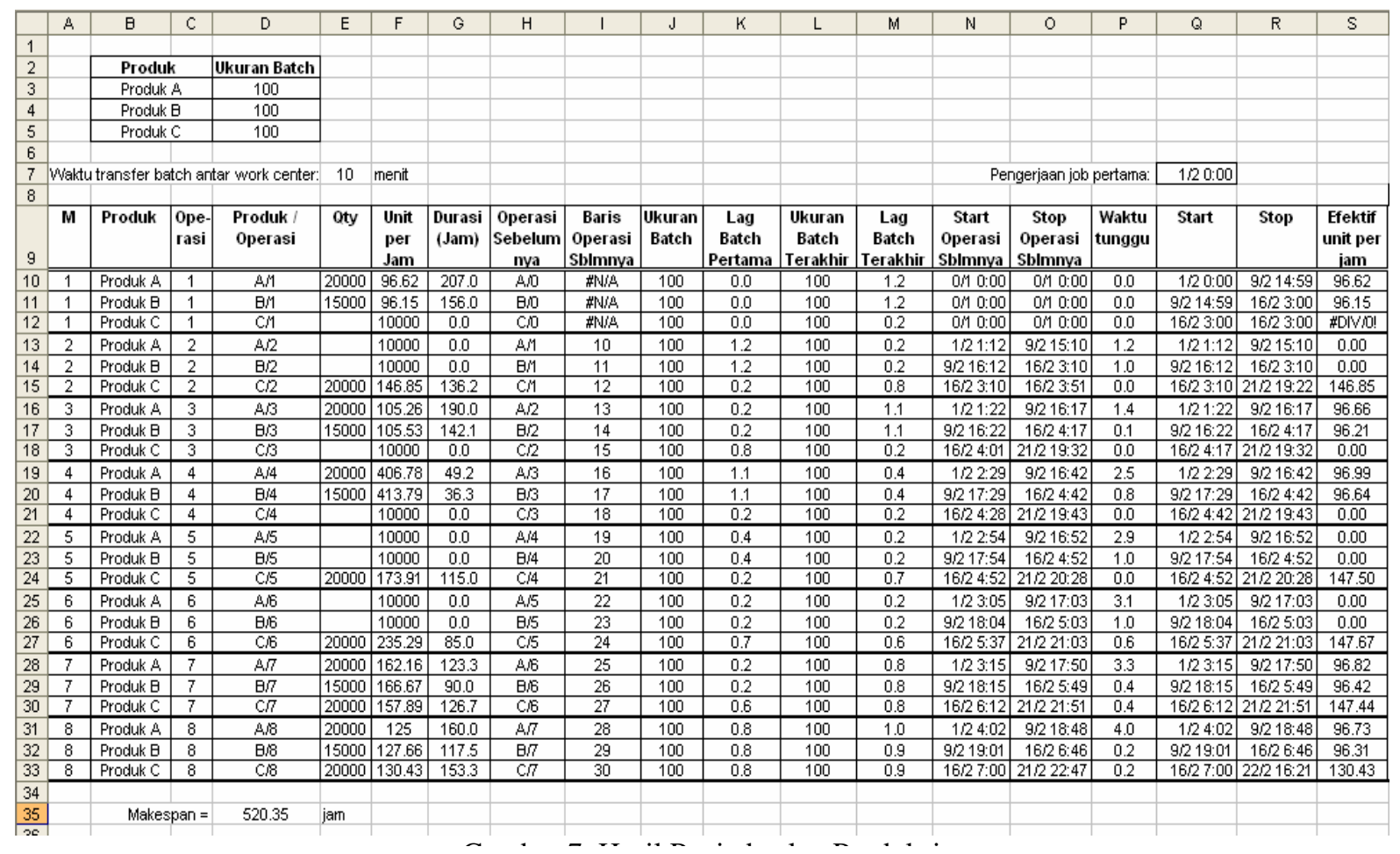

Gambar 7. Hasil Penjadwalan Produksi

dihasilkan nilai "A" yang akan digabungkan dengan C10 yang menunjukkan nomor operasi. Sebagai pemisah digunakan tanda "/" sehingga diperoleh hasil "A/1". Durasi tiap job dihitung berdasarkan kuantitas produk yang dikerjakan E10 dibagi dengan kecepatan produksi F10.

"Operasi Sebelumnya" ditentukan dengan perhitungan operasi saat ini dikurangi satu. RIGHT(B10,1) akan mengambil nilai produk yang dikerjakan saat ini (produk A). Saat ini produk A melakukan operasi-1 sehingga operasi sebelumnya adalah 0 (C10-1). Formula yang dibuat akan mencari nilai yang sesuai dari kolom "Operasi Sebelumnya" (H10) dengan perhitungan kolom "Produk/Operasi" dengan memakai fungsi MATCH. Karena sebelumnya tidak diketahui banyaknya baris yang akan dibuat dalam tabel jadwal produksi, maka ditetapkan formula yang akan mencocokkan dalam range $(\mathrm{D} \$ 1$ : D\$33). Jika tidak ditemukan nilai yang sesuai, hasil formula akan diberikan nilai FALSE. Karena nilai "A/0" tidak ditemukan dalam tabel, maka dihasilkan nilai "\#N/A".

Untuk menentukan ukuran batch, harus diketahui jenis produk yang dikerjakan saat ini. Kemudian ukuran batch dicari pada tabel ukuran batch yang sudah didefinisikan sebelumnya. Fungsi yang digunakan adalah VLOOKUP yang akan mencari ukuran batch untuk produk saat ini (B10) pada tabel ukuran batch ( $\$ \mathrm{~B} \$ 3: \$ \mathrm{D} \$ 5)$. Referensi kolom ukuran batch dari tabel transfer berada pada kolom ketiga. Jika terdapat batch dari operasi sebelumnya, cari kecepatan produksi pada kolom $\mathrm{F}$ untuk menghitung waktu untuk memproduksi batch pertama. Kemudian tambahkan waktu transfer untuk mendapatkan waktu lag untuk batch pertama (jam). Formula yang digunakan: $=\mathrm{IF}(\mathrm{ISERROR}(\mathrm{I} 10), 0,(\mathrm{~J} 10 /$ $\operatorname{INDEX}(\mathrm{F} \$ 1: \mathrm{F} \$ 33, \mathrm{I} 10,1))+(\mathrm{E} \$ 7 / 60))$.

Perhitungan ukuran batch terakhir dilakukan dengan mencari sisa pembagian antara "Quantity" dengan "Ukuran Batch". Jika sisa tersebut masih lebih besar dari ukuran batch, maka kembali ke ukuran batch. Formula untuk menentukan "Ukuran Batch Terakhir" adalah: = IF(MOD(E10,J10),MOD (E10,J10),J10). Waktu lag batch terakhir diperoleh dengan menambahkan waktu transfer batch dengan durasi produksi batch terakhir (L10/F10). Formula untuk menentukan "Lag Batch Terakhir" adalah: $=(\mathrm{E} \$ 7 / 60)+(\mathrm{L} 10 / \mathrm{F} 10)$. "Start Operasi Sebelumnya" adalah waktu start dari operasi sebelumnya [IF(IS

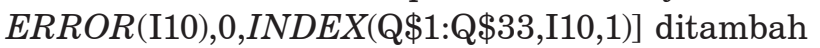
dengan waktu lag batch pertama [K10/24].

"Stop Operasi Sebelunya" adalah waktu stop dari operasi sebelumnya [IF(ISERROR(I10),0, $\operatorname{INDEX}(\mathrm{R} \$ 1: \mathrm{R} \$ 33, \mathrm{I} 10,1)]$ ditambah dengan waktu lag batch terakhir [M10/24]. "Start" adalah waktu mulai pengerjaan produk pada work center terkait. 

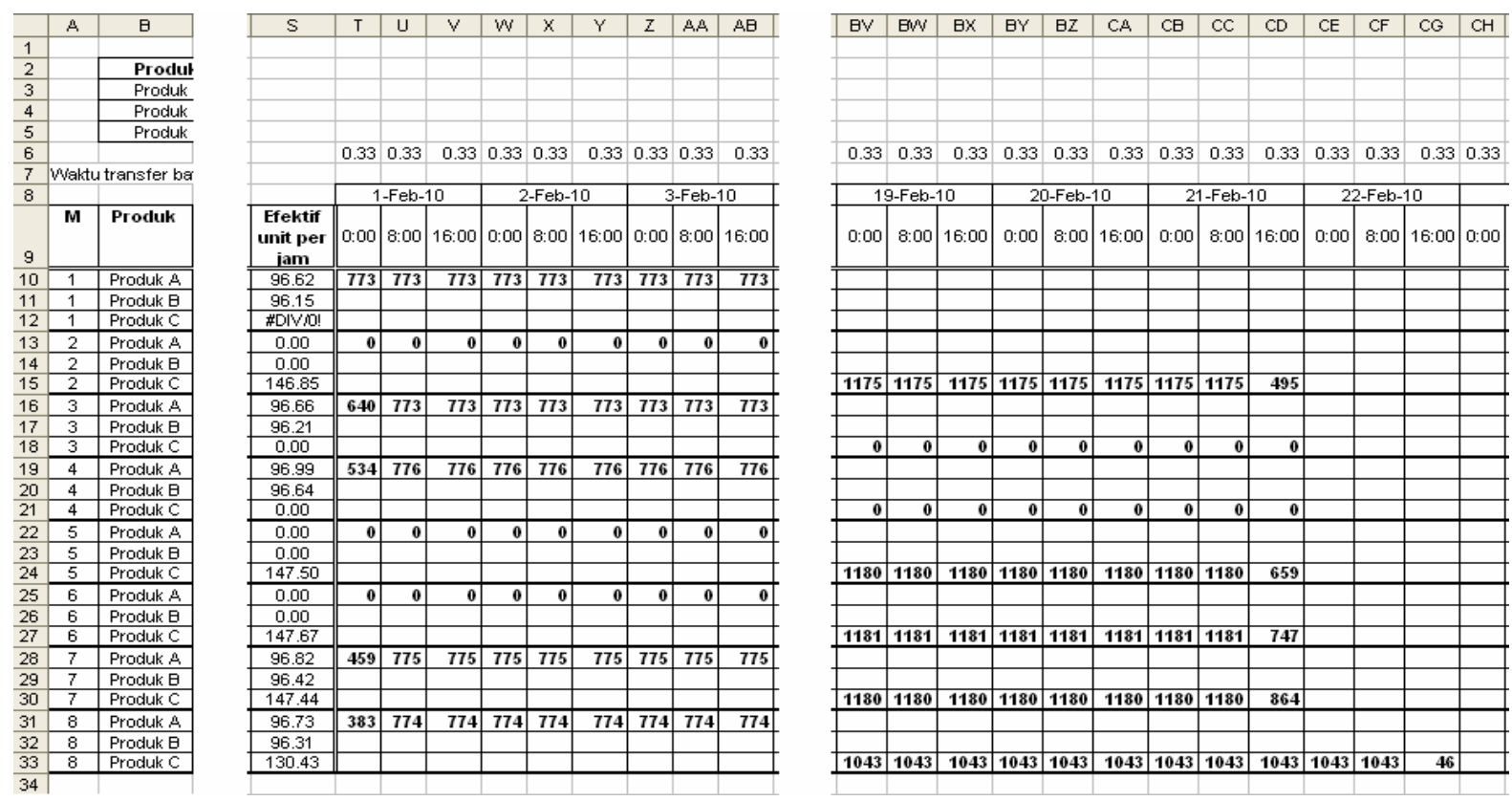

Gambar 8. Gantt Chart Penjadwalan Berdasarkan Urutan Penjadwalan JobA - JobB - JobC

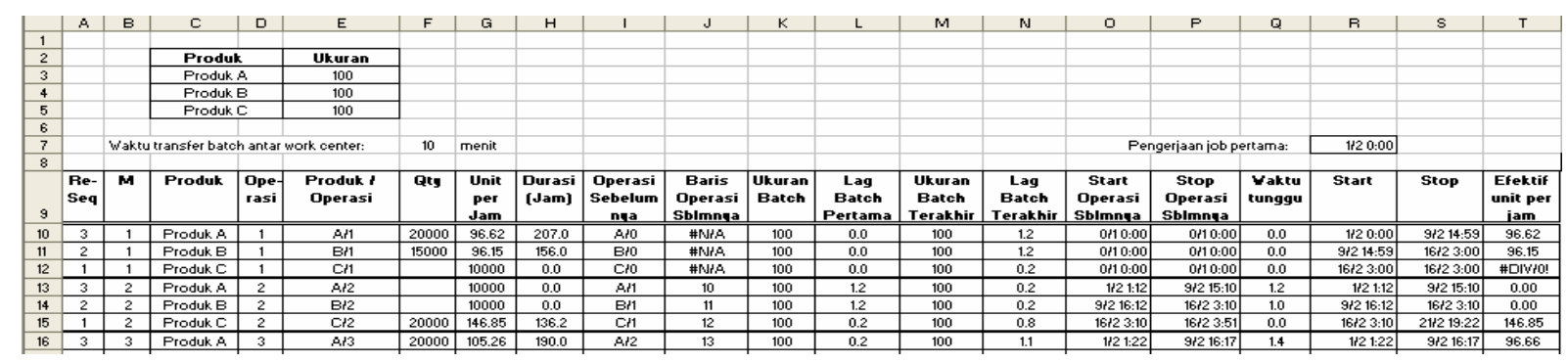

Gambar 9. Mengubah Urutan Pengerjaan Job

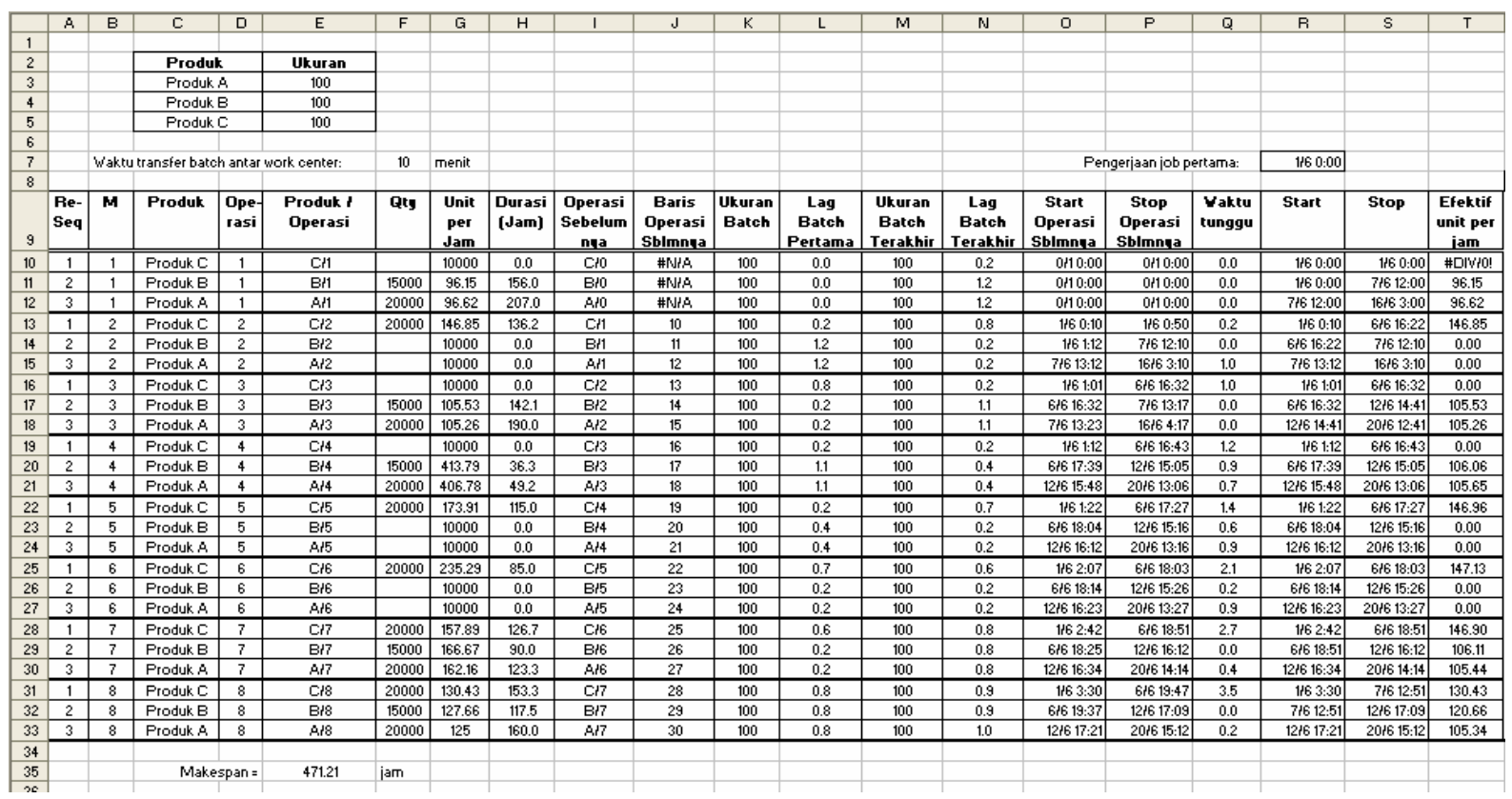

Gambar 10. Hasil Re-Sequencing berdasarkan Algoritma Palmer 
Tabel 7. Hasil Penjadwalan Produksi

\begin{tabular}{clcc}
\hline No. & \multicolumn{1}{c}{ Metode/Algoritma } & Urutan Penjadwalan & Makespan \\
\hline 1 & Algoritma Palmer & JobC - JobB - JobA & 471,21 jam \\
2 & Algoritma Dannenbring/Dudeck Teuton Smith & JobC - JobA - JobB & 471,17 jam \\
3 & - & JobA - JobB - JobC & 520,35 jam \\
4 & - & JobA - JobC - JobB & 488,16 jam \\
5 & - & JobB - JobA - JobC & 520,36 jam \\
6 & - & JobB - JobC - JobA & 485,07 jam \\
\hline
\end{tabular}

Langkah pertama untuk membuat formula adalah memeriksa $M$ saat ini dengan $M$ sebelumnya (A10 = A9). Jika $\mathrm{M}$ saat ini sama dengan $\mathrm{M}$ sebelumnya, maka waktu "Start" operasi saat ini adalah waktu "Stop Operasi Sebelumnya" (R9). Jika tidak, maka start operasi adalah tanggal mulai pengerjaan produk $(\$ Q \$ 7)$. Kemudian dicari nilai maksimum antara nilai hasil formula tersebut dengan waktu "Start Operasi Sebelumnya" (N10). Formula yang digunakan adalah: $=\operatorname{MAX}(\operatorname{IF}(\mathrm{A} 10=$ A9,R9,\$Q\$7),N10)

"Stop" adalah waktu selesai pengerjaan produk pada work center terkait. Penentuan waktu "Stop" adalah dengan mencari nilai maksimum antara waktu "Start" + "Durasi" (Q10+(G10/24)) dengan waktu "Stop Operasi Sebelumnya" (O10). Waktu tunggu adalah waktu menganggur yang terjadi akibat satu work center menunggu pekerjaan berikutnya. Ada 2 model perhitungan, yaitu untuk work center yang sama dan untuk work center berbeda. Jika work center saat ini sama dengan sebelumnya, maka waktu tunggu adalah waktu start dikurangi waktu stop pekerjaan sebelumnya. Sedangkan jika work center saat ini tidak sama dengan sebelumnya, maka waktu tunggu adalah waktu start dikurangi tanggal mulai pengerjaan produk. Karena waktu tunggu dihitung dalam unit jam, maka hasil perhitungan dikalikan 24, sehingga formula yang digunakan adalah: = $(\mathrm{Q} 10-\mathrm{IF}(\mathrm{A} 10=\mathrm{A} 9, \mathrm{R} 9, \$ \mathrm{Q} \$ 7)) * 24$.

Selain waktu tunggu, untuk tipe produksi berulang dapat dinilai performance jadwal produksi dengan menghitung kecepatan produksi yang efektif tiap work center sehingga dapat diketahui utilitas masingmasing work center. Semakin besar waktu tunggu work center, maka work center tersebut utilitasnya semakin rendah karena kecepatan produksi efektifnya di bawah kecepatan produksi normal. Sedangkan yang dimaksud dengan kecepatan produksi efektif adalah kuantitas produk (E10) dibagi dengan durasi pengerjaan masing-masing operasi [(R10-Q10/24]. Copy sel D10 dan paste pada sel D10:D33. Copy juga sel G10:S10 dan paste pada sel G11:S33.

Makespan adalah waktu penyelesaian seluruh job pada shop, dihitung berdasarkan selisih antara waktu stop job terakhir dengan waktu start job pertama. Formula yang digunakan: $=(\mathrm{R} 33-\mathrm{Q} 10) * 24$. Dari Gambar 7 tersebut dapat diketahui bahwa pada penjadwalan produksi dengan urutan penjadwalan JobA - JobB - JobC diperoleh makespan = 520,35 jam.

Berikut adalah langkah-langkah pembuatan gantt chart. (1)Menentukan time bucket adalah ukuran waktu yang digunakan untuk menampilkan satuan waktu yang dipakai dalam Gantt Chart. (2) Bagi jam kerja dalam 1 hari (24 jam) menjadi 3 time bucket sehingga 1 time bucket mempunyai ukuran 8 jam. (3) Buat penanggalan Gantt Chart dimulai dari tanggal pengerjaan job yang pertama. (4) Menentukan jam mulai time bucket dimana jam mulai masing-masing time bucket ditentukan berdasarkan ukuran time bucket. (5) Menentukan time bucket selanjutnya. (6) Menentukan tanggal selanjutnya. Tanggal selanjutnya ditentukan berdasarkan jam permulaan time bucket yang bernilai 0:00. Gabungkan sel W8, X8 dan Y8 dengan fungsi Merge Cells. Selanjutnya copy sel W8 dan paste pada sel Z8:AB8.

Kemudian, formula alokasi time bucket dibuat. Pada sel T10 ketikkan formula berikut: $=\mathrm{IF}(\mathrm{OR}(\$ \mathrm{R} 10<=\mathrm{T} \$$ 9,\$Q10>=U\$9),"', IF(AND(\$Q10>=T\$9,\$R10<U\$9),\$G10/ $24, \mathrm{IF}(\mathrm{AND}(\$ \mathrm{Q} 10>=\mathrm{T} \$ 9, \$ \mathrm{Q} 10<\mathrm{U} \$ 9), \mathrm{U} \$ 9-\$ \mathrm{Q} 10, \mathrm{IF}(\mathrm{A}$ $\mathrm{ND}(\$ \mathrm{R} 10>\mathrm{T} \$ 9, \$ \mathrm{R} 10<\mathrm{U} \$ 9), \$ \mathrm{R} 10-\mathrm{T} \$ 9, \mathrm{~T} \$ 6)) * 24 * \$ \mathrm{~S} 10)$. Selanjutnya copy formula tersebut dan paste pada sel T10:CJ33. Hasil Gantt Chart adalah seperti pada Gambar 8.

Jadwal produksi tersebut dapat dilakukan resequencing sesuai dengan urutan penjadwalan berdasarkan algoritma penjadwalan produksi yang lain. Re-sequencing dapat dilakukan secara manual (dengan memasukkan ulang data masing-masing job sesuai urutan penjadwalan yang baru) atau berdasarkan langkah berikut: tambahkan 1 kolom di sebelah kiri tabel penjadwalan dengan menu Insert $>$ Columns, kemudian beri nama/judul kolom yang baru: Re-Seq, selanjutnya ubah urutan pengerjaan job berdasarkan algoritma Palmer dengan urutan penjadwalan: JobC - JobB - JobA seperti tampak pada Gambar 9.

Selanjutnya blok tabel pada range sel A10: G12. Setelah itu urutkan job berdasarkan urutan 
penjadwalan yang baru dengan fasilitas menu Data > Sort, pilih No header row. Karena urutan pengerjaan job berada pada kolom A, pilih Column A pada kategori Sort by dengan tipe Ascending. Hal yang sama dilakukan pada work center 2 s/d 8 . Hasil re-sequencing (berdasarkan algoritma Palmer) seperti tampak pada Gambar 10. Hasil re-sequencing selengkapnya disajikan pada tabel 10. Dari tabel 10 tersebut dapat diperoleh penjadwalan terbaik yang dapat meminimasi makespan, yaitu berdasarkan Algoritma Dannenbring atau berdasarkan Algoritma Dudeck Teuton Smith dengan urutan penjadwalan: JobC - JobA - JobB dengan makespan 471,17 jam.

\section{SIMPULAN}

Berdasarkan penjadwalan produksi dengan pendekatan konvensional diperoleh penjadwalan terbaik berdasarkan Alg. Palmer dengan urutan penjadwalan: JobC - JobB - JobA atau berdasarkan Alg. Dudeck Teuton Smith dan Alg. Dannenbring dengan urutan penjadwalan: JobC - JobA - JobB, masing-masing dengan makespan 893,7 jam. Sedangkan penjadwalan produksi dengan software aplikasi microsoft excel diperoleh penjadwalan terbaik dengan urutan penjadwalan: JobC - JobA JobB dengan makespan 471,17 jam, sehingga dapat diperoleh hasil penjadwalan dengan makespan yang lebih baik. Meski penjadwalannya sama (JobC - JobA $J o b \mathrm{~B})$, pada penjadwalan produksi dengan software microsoft excel dapat diperoleh makespan yang lebih baik karena pada tipe produksi berulang, operasi berikutnya dapat dilakukan setelah waktu lag dari waktu mulai operasi sebelumnya. Sedangkan pada pendekatan konvensional, operasi berikutnya baru bisa dilakukan setelah operasi sebelumnya diselesaikan tuntas terlebih dahulu. Kelebihan lainnya dari penjadwalan produksi dengan software aplikasi microsoft excel adalah bahwa Gantt Chart tidak perlu dibuat secara manual sehingga dapat mengurangi resiko terjadinya kesalahan dalam penghitungan makespan.

\section{DAFTAR PUSTAKA}

Etheridge, D. Microsoft Excel Tutorial-Free \& Online, http://www.baycongroup.com/el0.htm. akses tanggal 17 Desember 2009.

Hejazi, S.R., and Saghafian, S., 2005. Flowshop-Scheduling Problems with Makespan Criterian: A review. International Journal of Production Research 43(14): 2895-2929.

Pinedo, M, 1985. Scheduling; Theory, Algorithms and Systems, Prentice-Hall Inc, Engle Wood Cliffs, New Jersey.

Rahayu, S.L., 2000. Pengurutan \& Penjadwalan Job pada Mesin, Surabaya: Untag Press.

Taillard, E., 1993. Benchmarks for Basic Scheduling Problem, European Journal of Operational Research, 62(2): 278-285. 